\title{
Impact of Clay Particles in Concrete
}

\author{
S. Selvamamundi ${ }^{1}$, Dr. N. Mahendran ${ }^{2}$, Dr. S. Anuradha ${ }^{3}$ \\ ${ }^{1}$ PG Scholar, PSNA College of Engineering and Technology, Dindigul-624622, Tamil Nadu, India \\ ${ }^{2}$ Professor, PSNA College of Engineering and Technology, Dindigul-624622, Tamil Nadu, India \\ ${ }^{3}$ Professor, PSNA College of Engineering and Technology, Dindigul-624622, Tamil Nadu, India
}

\begin{abstract}
The rising costs of building construction in developing countries have been a source of concern to government and private developers. This study investigated the use of clay soil as partial replacement for fine aggregate in the concrete production. Clay was used to replace fine aggregates from $0 \%$ (conventional), $5 \%, 10 \%$ and $15 \%$ with the concrete of grade $M_{20}$. For this study, concrete cubes measuring $150 \times 150 \times 150 \mathrm{~mm}$ and cylinders measuring $150 \times 300 \mathrm{~mm}$ were casted and their compressive strengths and split tensile strengths were evaluated at 7, 14 and 28 days. From this study, it has been encountered that the increase in percentage of clay in concrete cubes and cylinders led to a corresponding reduction in compressive and split tensile strength values due to the reduction in the bond strength in-between the concrete ingredients. It is overcome by, Alumina powder and Sodium Phosphate which is considered as the materials that provide better bond strength has been considered as additive admixtures to the concrete. These two ingredients Alumina \& Sodium Phosphate were added to the clay-concrete from $5 \%, 10 \%$ and $15 \%$ with water cement ratio as 0.5 . From the results obtained from this new clay-concrete with bonding admixtures, the compressive strength and split tensile strength has been found to increase gradually by increase in the admixture to the concrete. It is also to be noted that the increase in compressive and split tensile strength of clay-concrete has crossed the strength of the conventional concrete with a considerable value. So, it could be concluded as that the clay can be used as a replacement to fine aggregate in concrete with bonding admixtures to get a hybrid concrete with better performance than the conventional concrete.
\end{abstract}

Keywords: Compressive strength, Split tensile strength, EDAX result, Alumina powder, Sodium phosphate

\section{Introduction}

Concrete is a construction material which is composed of three main materials, these being cement, water and aggregates (sand, natural gravel or crushed stone).Sometimes, an admixture, this being an additional material, is added in order to change or modify certain properties (such as water- repellent, on colouring agent or to retard a hasten setting)of concrete. The chemically active constituent of concrete is cement. The reactivity of cement is only guaranteed and achieved on mixing it with water. Aggregates do not have a role to play in the chemical reactions within concrete but they are very useful because they act as economic filler materials with good resistance to volume changes, which occur in concrete after mixing. Another important aspect of aggregates is that they improve the durability of concrete. Concrete aggregates can sometimes contain impurities like clay particles which can have an impact on the concrete properties.

Clay coatings consist of clay particles that are held tightly to aggregate surface. Because the material usually adheres to the aggregate even after the concrete is mixed, it is believed to interfere with the aggregate-cement paste bond. Unlike clay coating, dust coating are easily removed during mixing and affect concrete performance by increasing the amount of finess dispersed in the mix.

Coatings containing clay, silt, and organic matter are found naturally in the overlying layers of the deposit or are artificially placed on the aggregate during processing. This article is limited to the impact of clay particles on concrete compressive strength.
1.1. Clay

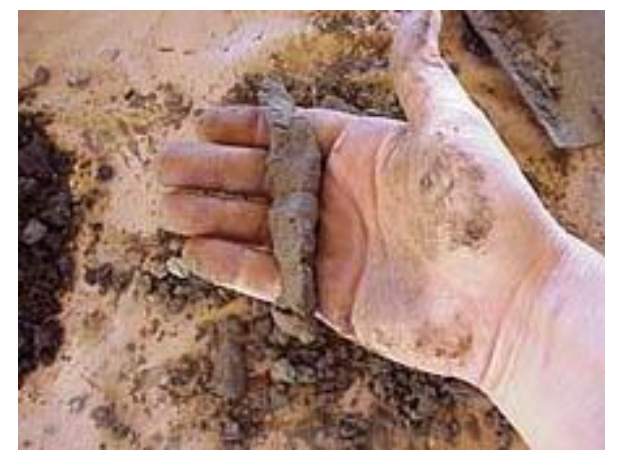

Figure 1: Clay

Clays are distinguished from other fine-grained soils by differences in size and mineralogy. Silts, which are finegrained soils that do not include clay minerals, tend to have larger particle sizes than clays. There is, however, some overlap in particle size and other physical properties, and many naturally occurring deposits include both silts and clay. The distinction between silt and clay varies by discipline. Geologists and soil scientists usually consider the separation to occur at a particle size of $2 \mu \mathrm{m}$ (clays being finer than silts), sedimentologists often use 4-5 $\mu \mathrm{m}$, and colloid chemists use $1 \mu \mathrm{m}$. Geotechnical engineers distinguish between silts and clays based on the plasticity properties of the soil, as measured by the soils' Atterberg limits. ISO 14688 grades clay particles as being smaller than $2 \mu \mathrm{m}$ and silt particles as being larger.

\subsection{Properties of Clay}

Clay is one of the oldest building materials on Earth, among other ancient, naturally-occurring geologic materials such as stone and organic materials like wood. Between one-half and 


\section{International Journal of Science and Research (IJSR) \\ ISSN (Online): 2319-7064 \\ Index Copernicus Value (2013): 6.14 | Impact Factor (2015): 6.391}

two-thirds of the world's population, in traditional societies as well as developed countries, still live or work in a building made with clay as an essential part of its load-bearing structure. Also a primary ingredient in many natural building techniques, clay is used to create adobe, cob, cordwood, and rammed earth structures and building elements such as wattle and daub, clay plaster, clay render case, clay floors and clay paints and ceramic building material. Clay was used as a mortar in brick chimneys and stone walls where protected from water.

\subsection{Alumina Powder}
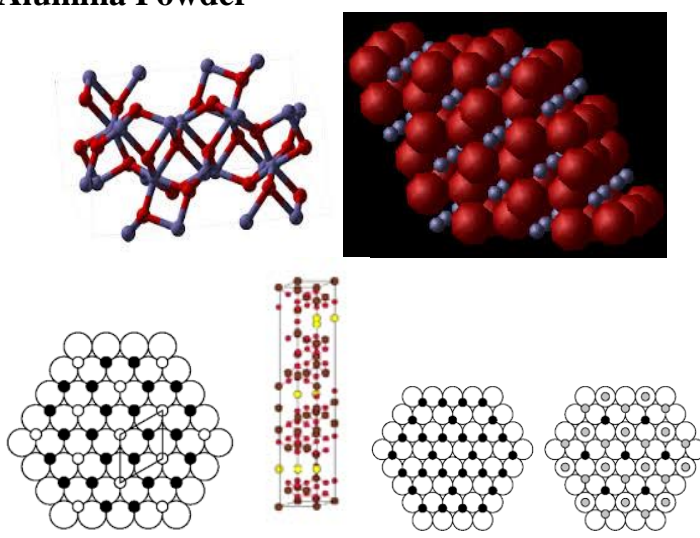

Figure 2: Alumina Powder Reaction

Native Alumina $\left(\mathrm{Al}_{2} \mathrm{O}_{3}\right)$ is found as the mineral corundum. Most bauxite is refined by the Bayer process to remove impurities and produce a nominal $99.5 \% \mathrm{Al}_{2} \mathrm{O} 3$ product.

\subsection{Tetrasodium Phosphate}

It is colorless, transparent, crystalline chemical compound with the formula $\mathrm{Na}_{4} \mathrm{P}_{2} \mathrm{O}_{7}$. It is a salt composed of phosphate and sodium ions.

\section{Basic Material Tests}

Table 1: Tested Results of Specific Gravity of Cement

\begin{tabular}{|l|c|}
\hline \multicolumn{1}{|c|}{ Description } & Weight (gm) \\
\hline Weight of empty bottle (W1) & 34 \\
\hline Weight of bottle + cement (W2) & 103 \\
\hline Weight of bottle + cement + kerosene (W3) & 179 \\
\hline Weight of bottle + Kerosene (W4) & 132 \\
\hline
\end{tabular}

Specific gravity of cement

$=(\mathrm{W} 2-\mathrm{W} 1) /((\mathrm{W} 2-\mathrm{W} 1)-(\mathrm{W} 3-\mathrm{W} 4))$

$=(103-34) /((103-34)-(179-132))$

$=3.136$

Table 2: Tested Results of Specific Gravity of Fine Aggregate

\begin{tabular}{|c|c|}
\hline Description & Weight (gm) \\
\hline Weight of empty mould (W1) & 633 \\
\hline Weight of mould + Fine Aggregate (W2) & 1170 \\
\hline Weight of mould + Fine Aggregate + water (W3) & 1868 \\
\hline Weight of mould + water (W4) & 1540 \\
\hline
\end{tabular}

Specific gravity of fine aggregate

$=(\mathrm{W} 2-\mathrm{W} 1) /((\mathrm{W} 2-\mathrm{W} 1)-(\mathrm{W} 3-\mathrm{W} 4)$

$=537 /(537-328)$

$=2.57$
Table 3: Tested Results of Specific Gravity of Coarse Aggregate

\begin{tabular}{|c|c|}
\hline DESCRIPTION & $\begin{array}{c}\text { Weight } \\
\text { (kg) }\end{array}$ \\
\hline weight of empty basket (W1) & 2.57 \\
\hline Weight of basket + coarse aggregate (W2) & 7.57 \\
\hline Weight of basket + coarse aggregate + water, (W3) & 4.24 \\
\hline Weight of basket + water, (W4) & 2.48 \\
\hline Weight of coarse aggregate in basket, (W2-W1) & 5 \\
\hline Weight of equal volume of water (W2-W1) - (W3-W4) & 1.72 \\
\hline
\end{tabular}

Weight of equal volume of water $=(\mathrm{W} 2-\mathrm{W} 1) /((\mathrm{W} 2-\mathrm{W} 1)-$ (W3-W4))

$=5 / 1.72$

Specific gravity of coarse aggregate $=2.82$

Table 4: Replacement percentage of fine aggregate

\begin{tabular}{|c|c|}
\hline Replacement \% of Clay Content with FA & Mix Design \\
\hline For conventional concrete & $1: 1.493: 3.183$ \\
\hline 5\% of partially replacement of F.A & $1: 1.48: 3.183$ \\
\hline 10\% of partially replacement of F.A & $1: 1.497: 3.183$ \\
\hline 15\% of partially replacement of F.A & $1: 1.5: 3.183$ \\
\hline
\end{tabular}

\section{Selection of Clay and Soil}

\subsection{Swelling Index}

Sample from PSNA CET

Volume of clay in water $=19 \mathrm{ml}$

Volume of clay in kerosene $=18 \mathrm{ml}$

$\mathrm{V}_{\mathrm{d}}=$ volume of clay in water

$\mathrm{V}_{\mathrm{k}}=$ volume of clay in kerosene

Swelling index $=\mathrm{Vd}-\mathrm{Vk} / \mathrm{Vk} \times 100 \%=5.55 \%$

Table 5: Swelling Limits (IS 2720 Part- 40 \& 41) 1997

\begin{tabular}{|c|c|c|}
\hline S. No & Swelling limits in $\%$ \\
\hline 1 & Low & $0-15$ \\
\hline 2 & Medium & $10-35$ \\
\hline 3 & High & $20-55$ \\
\hline 4 & Very high & 35 above \\
\hline
\end{tabular}

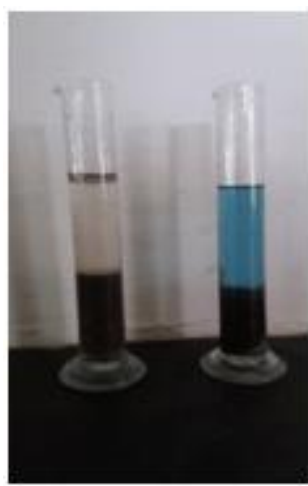

Figure 3: Diagram of Swelling Index test

\subsection{EDAX results for clay}




\section{International Journal of Science and Research (IJSR) \\ ISSN (Online): 2319-7064}

Index Copernicus Value (2013): 6.14 | Impact Factor (2015): 6.391

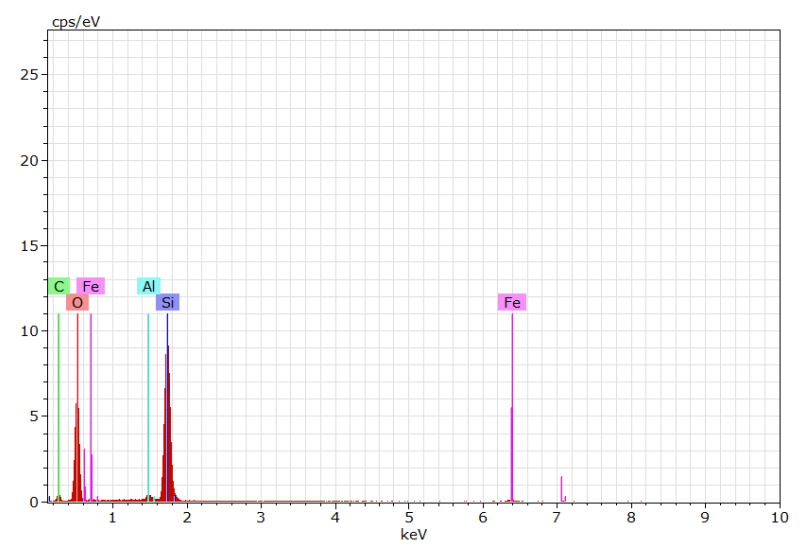

Figure 4: Graph results for clay

1) Silica content $=69.97 \%$

2) Iron content $=8 \%$

\subsection{EDAX results for soil}

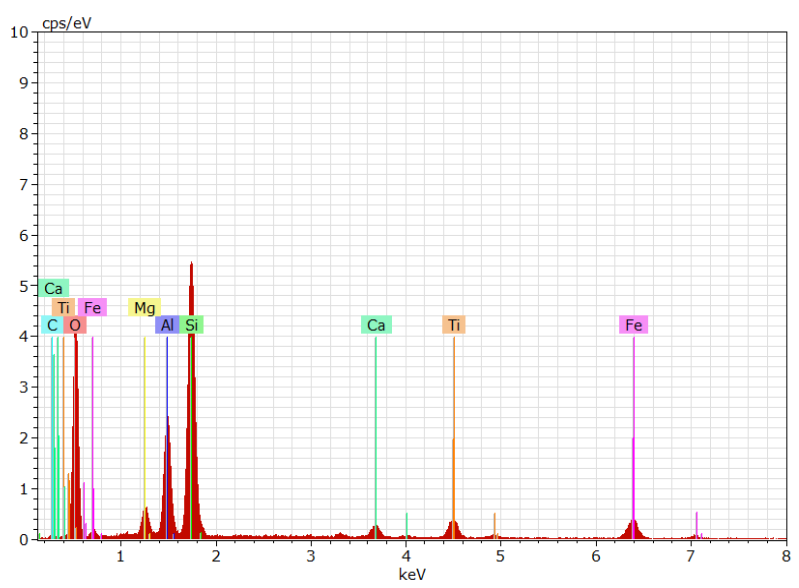

Figure 5: Graph results for soil
1) silica content $=79.26 \%$

2) iron content $=8.67 \%$

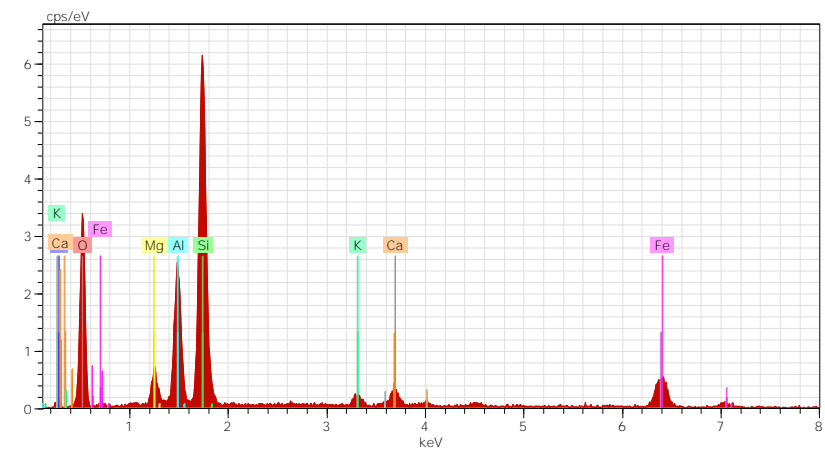

Figure 6: Chemical Test Result

Table 6: Chemical Properties Tabulation

\begin{tabular}{|c|c|c|}
\hline Elements & $\mathrm{An}$ & Percentage Of Elements \\
\hline $\mathrm{O}$ & 8 & 57.75 \\
\hline $\mathrm{Si}$ & 14 & 23.54 \\
\hline $\mathrm{C}$ & 1 & 6.00 \\
\hline $\mathrm{Al}$ & 13 & 9.69 \\
\hline $\mathrm{Mg}$ & 12 & 3.05 \\
\hline $\mathrm{Fe}$ & 26 & 5.40 \\
\hline $\mathrm{Ca}$ & 20 & 1.44 \\
\hline $\mathrm{K}$ & 19 & 0.71 \\
\hline
\end{tabular}

Table 7: EDAX results for clay

\begin{tabular}{|c|c|c|c|c|c|c|c|}
\hline El & AN & Series & $\begin{array}{c}\text { Unn.c } \\
\text { Wt (\%) }\end{array}$ & $\begin{array}{c}\text { Norm.c } \\
\text { Wt (\%) }\end{array}$ & $\begin{array}{c}\text { Atom c } \\
\text { Wt (\%) }\end{array}$ & Error & $\begin{array}{c}\text { (1 sigma) } \\
\text { Wt (\%) }\end{array}$ \\
\hline $\mathrm{O}$ & 8 & K Series & 51.92 & 51.93 & 66.26 & & 6.95 \\
\hline $\mathrm{Si}$ & 14 & K Series & 19.28 & 19.29 & 14.02 & & 0.86 \\
\hline $\mathrm{Al}$ & 13 & K Series & 9.50 & 9.50 & 7.19 & & 0.50 \\
\hline $\mathrm{C}$ & 6 & K Series & 2.77 & 2.77 & 4.70 & & 1.07 \\
\hline $\mathrm{Fe}$ & 26 & K Series & 7.93 & 7.93 & 2.90 & & 0.29 \\
\hline $\mathrm{Mg}$ & 12 & K Series & 2.71 & 2.71 & 2.28 & & 0.20 \\
\hline $\mathrm{Ti}$ & 22 & K Series & 4.10 & 4.10 & 1.75 & & 0.17 \\
\hline $\mathrm{Ca}$ & 20 & K Series & 1.77 & 1.77 & 0.90 & & 0.10 \\
\hline & & 99.98 & 100.00 & 100.00 & & \\
\hline
\end{tabular}

Table 8: EDAX results for soil

\begin{tabular}{|c|c|c|c|c|c|c|c|}
\hline El & AN & Series & $\begin{array}{c}\text { Unn.c } \\
\text { Wt (\%) }\end{array}$ & $\begin{array}{c}\text { Norm.c } \\
\text { Wt (\%) }\end{array}$ & $\begin{array}{c}\text { Atom c } \\
\text { Wt (\%) }\end{array}$ & Error & $\begin{array}{c}\text { (1 sigma) } \\
\text { Wt (\%) }\end{array}$ \\
\hline $\mathrm{O}$ & 8 & K Series & 69.41 & 58.90 & 64.43 & & 9.94 \\
\hline $\mathrm{C}$ & 6 & K Series & 14.70 & 12.48 & 18.18 & & 4.05 \\
\hline $\mathrm{Si}$ & 14 & K Series & 30.47 & 25.85 & 18.11 & & 1.36 \\
\hline $\mathrm{Al}$ & 13 & K Series & 1.42 & 1.21 & 0.78 & & 0.13 \\
\hline $\mathrm{Fe}$ & 26 & K Series & 1.85 & 1.57 & 0.49 & & 0.15 \\
\hline \multicolumn{7}{|r|}{} & \multicolumn{7}{|l}{117.86} & 100.00 & 100.00 & & \\
\hline
\end{tabular}

\subsection{Particle Size Distribution}




\section{International Journal of Science and Research (IJSR) \\ ISSN (Online): 2319-7064}

Index Copernicus Value (2013): 6.14 | Impact Factor (2015): 6.391

Table 9: Particle Size Distribution

\begin{tabular}{|c|c|c|c|c|c|c|}
\hline \multirow{2}{*}{$\begin{array}{r}\text { I.S.Sieves } \\
(\mathrm{mm})\end{array}$} & \multicolumn{3}{|c|}{ Weight retained (gms) } & \multirow{2}{*}{$\begin{array}{c}\text { Cumulative } \\
\text { weight retained } \\
\text { (gms) }\end{array}$} & \multirow{2}{*}{$\begin{array}{l}\text { Cumulative \% } \\
\text { retained (gms) }\end{array}$} & \multirow{2}{*}{$\begin{array}{c}\% \\
\text { Finer }\end{array}$} \\
\hline & $\begin{array}{c}\text { Empty } \\
\text { weight of } \\
\text { sieve }\end{array}$ & $\begin{array}{l}\text { Retained } \\
\text { weight of } \\
\text { sieve }\end{array}$ & $\begin{array}{c}\text { Retained } \\
\text { weight of sand }\end{array}$ & & & \\
\hline 4.75 & 417.50 & 418.50 & 1 & 1 & 1 & 100 \\
\hline 2.36 & 392.50 & 444.40 & 51.90 & 51.90 & 5.19 & 94.81 \\
\hline 1.18 & 357.00 & 565.00 & 208.00 & 259.90 & 25.90 & 74.10 \\
\hline $600 \mu$ & 340.00 & 562.50 & 222.50 & 482.40 & 48.24 & 51.76 \\
\hline $300 \mu$ & 369.00 & 712.50 & 343.50 & 825.90 & 82.59 & 17.41 \\
\hline $150 \mu$ & 319.00 & 397.00 & 78.00 & 903.90 & 90.39 & 9.61 \\
\hline $75 \mu$ & 305.50 & 370.10 & 64.60 & 968.50 & 96.85 & 3.15 \\
\hline Pan & 328.50 & 354.00 & 25.50 & 994.00 & 99.40 & 0.60 \\
\hline
\end{tabular}

Finessmodulas $=$ total sum of the cumulative $\%$ retained $/=16.56 \mathrm{~N} / \mathrm{mm}^{2}$

1000

$=496.27 / 1000$

\subsection{For Split tensile strength}

$=0.496$

\section{Calculations}

\subsection{For Compressive strength}

$\mathrm{P}=21000 * 9.81=206010 \mathrm{~N}$.

Split tensile strength $=2 \mathrm{P} / \pi \mathrm{dl}$

$=412020 / 141300$

$=2.91 \mathrm{~N} / \mathrm{mm}^{2}$

Load $=38000 * 9.81=372780 \mathrm{~N}$.

5. Test Results

Compressive strength $=$ load $/$ area

$=372780 / 22500$

Table 10: Test results for cubes and cylinders

\begin{tabular}{|c|c|c|c|c|c|c|c|}
\hline \multirow{2}{*}{ Specimen } & \multirow{2}{*}{ Replaced Fine Aggregate } & \multicolumn{2}{|c|}{$\begin{array}{l}\text { @ } 7 \text { days } \\
\left.\text { (in } \mathbf{N} / \mathbf{m m}^{2}\right)\end{array}$} & \multicolumn{2}{|c|}{$\begin{array}{l}\text { @ } 14 \text { days } \\
\left.\text { (in } \mathrm{N} / \mathbf{m m}^{2}\right)\end{array}$} & \multicolumn{2}{|c|}{$\begin{array}{l}\text { @ } 28 \text { days } \\
\text { (in } \mathbf{N} / \mathbf{m m}^{2} \text { ) }\end{array}$} \\
\hline & & $\begin{array}{l}\text { For } \\
\text { cube }\end{array}$ & $\begin{array}{c}\text { For } \\
\text { cylinder }\end{array}$ & $\begin{array}{l}\text { For } \\
\text { cube }\end{array}$ & $\begin{array}{c}\text { For } \\
\text { cylinder }\end{array}$ & For cube & $\begin{array}{c}\text { For } \\
\text { cylinder }\end{array}$ \\
\hline Conventional concrete & & 21.8 & 2.63 & 22.0 & 2.91 & 23.56 & 2.94 \\
\hline \multirow{3}{*}{ Clay added concrete } & For 5\% & 17.2 & 2.22 & 18.15 & 3.05 & 19.56 & 2.95 \\
\hline & For $10 \%$ & 18.5 & 2.51 & 19.0 & 2.90 & 19.46 & 2.86 \\
\hline & For $15 \%$ & 19.03 & 2.75 & 19.8 & 2.77 & 20.11 & 3.17 \\
\hline \multirow{3}{*}{ Alumina added concrete } & For $5 \% \mathrm{C}+2 \% \mathrm{~A}$ & 23.2 & 2.82 & 23.8 & 3.00 & 23.11 & 3.56 \\
\hline & For $10 \% \mathrm{C}+4 \% \mathrm{~A}$ & 23.5 & 2.92 & 24.0 & 2.97 & 22.86 & 3.68 \\
\hline & For $15 \% \mathrm{C}+6 \% \mathrm{~A}$ & 24.2 & 2.95 & 24.5 & 2.96 & 24.56 & 3.39 \\
\hline \multirow{3}{*}{$\begin{array}{l}\text { Alumina + Sodium Phosphate added } \\
\text { concrete }\end{array}$} & For $5 \% \mathrm{C}+2 \% \mathrm{~A}+1.5 \%$ S.P & 16.56 & 2.2 & 18.31 & 2.22 & 17.17 & 2.29 \\
\hline & For $10 \% \mathrm{C}+4 \% \mathrm{~A}+3 \%$ S.P & 17.44 & 2.1 & 18.53 & 2.3 & 17.89 & 2.97 \\
\hline & For $15 \% \mathrm{C}+6 \% \mathrm{~A}+4.5 \%$ S.P & 17.87 & 2.4 & 19.62 & 2.6 & 18.97 & 2.86 \\
\hline Conventional + Alumina & & 22.22 & 2.82 & 23.15 & 2.96 & 23.7 & 2.85 \\
\hline Conventional + Sodium Phosphate & & 19.95 & 2.76 & 19.85 & 2.79 & 19.85 & 2.34 \\
\hline
\end{tabular}

Table 11: Comparison between 7 and 28 days for both cubes and cylinders

\begin{tabular}{|c|c|c|c|c|c|}
\hline \multirow[t]{2}{*}{ Specimen } & \multirow[t]{2}{*}{ Replaced Fine Aggregate } & \multicolumn{2}{|c|}{$\begin{array}{l}\text { @ } 7 \text { days } \\
\text { (in } \mathrm{N} / \mathrm{mm}^{2} \text { ) }\end{array}$} & \multicolumn{2}{|c|}{$\begin{array}{l}\text { @ } 28 \text { days } \\
\text { (in } \mathrm{N} / \mathrm{mm}^{2} \text { ) }\end{array}$} \\
\hline & & For cube & For cylinder & For cube & For cylinder \\
\hline Conventional concrete & & 21.8 & 2.63 & 23.56 & 2.94 \\
\hline \multirow[t]{2}{*}{ Alumina added concrete } & For $5 \% \mathrm{C}+1.5 \% \mathrm{~A}$ & 21.16 & 2.92 & 21.96 & 22.76 \\
\hline & For $15 \% \mathrm{C}+4.5 \% \mathrm{~A}$ & 22.89 & 2.98 & 2.97 & 2.89 \\
\hline \multirow{2}{*}{$\begin{array}{l}\text { Alumina + Sodium } \\
\text { Phosphate added concrete }\end{array}$} & For 5\% C + 1.5\% A + 2 \% S.P & 20.89 & 2.76 & 20.976 & 2.729 \\
\hline & For $15 \% \mathrm{C}+4.5 \% \mathrm{~A}+6 \% \mathrm{~S} . \mathrm{P}$ & 20.957 & 2.866 & 21.01 & 2.896 \\
\hline
\end{tabular}

\section{Conclusion}

This study shows an alternative approach of replacing fine aggregate with clay particles in concrete. A comparative study of different percentage of clay particles to be replaced.Finally it is concluded that, $1.5 \%$ of decrease in Alumina powder and $1.5 \%$ of increase in Sodium phosphate provides the value of conventional concrete. The EDAX results for all the cubes and cylinders are obtained to compare the compressive strength, split tensile strength results for both conventional and clay added concrete.

\section{References}

[1] AlexandreBogas J , Rita Nogueira and Nuno G. Almeida (2013), 'Influence of mineral additions and different compositional parameters on the shrinkage of structural expanded clay lightweight', concrete Materials and Design, Vol 56 pp. 1039-1048.

[2] AlexandreBogas.J , de Brito.J and Cabaço.J (2014), 'Long-term Behaviour of concrete produced with recycled lightweight expanded clay aggregate concrete', 


\section{International Journal of Science and Research (IJSR) \\ ISSN (Online): 2319-7064}

Index Copernicus Value (2013): 6.14 | Impact Factor (2015): 6.391

Construction and Building Materials, Vol 65 pp. 470479.

[3] SuksunHorpibulsuk ,RunglawanRachan AvirutChinkulkijniwat , YuttanaRaksachon and ApichatSuddeepong (2010), 'Analysis of strength development in cement-stabilized silty clay from microstructural considerations', Construction and Building Materials, Vol pp. 24.

[4] Twubahimana Joseph Desire and Bereyaho Leopold (2013), 'Impact of clay particle on concrete compressive Strength', International Research Journal on Engineering Vol. 1(2), pp. 049-056. 